Exfoliative cytology of the colon ${ }^{5}$ is difficult because of faecal debris. Painstaking bowel preparation and skilful interpretation of the cytological findings are essential, so that it is doubtful whether this method has a role in screening.

How then can tumours of the large bowel be diagnosed at their earliest stage ? In practice this implies constant clinical awareness. Slight changes in bowel habit or rectal bleeding must be regarded as danger signs which are not to be ignored. The test for occult blood in the stools is simple and even if bedevilled by false positive and negative results at least it gives some rough screening in a symptomatic patient. If the test is performed on several specimens a false negative is unlikely to occur. The sigmoidoscope is easy to use and should be employed at every opportunity in routine examinations ; two-thirds of large bowel growths are within its reach, and, perhaps more important, polyps can be detected and removed before malignant change can take place.

\section{Oral Contraceptives and Alopecia}

The impression exists that oral contraceptives may be a cause of alopecia, but firm evidence seems to be lacking. The critical assessment of the pharmacologically induced side-effects of any drug is complicated by the frequency of symptoms induced by suggestion. Some women who are taking oral contraceptives admit that they feel guilty in doing so, and this attitude of mind gives rise to a further group of symptoms - so-called scapegoat symptoms' - which are the result of increased self-observation. The evidence that loss of hair is caused by these drugs is therefore unusually difficult to evaluate. Two patterns of hair loss have been attributed to them, alopecia areata and diffuse alopecia.

Alopecia areata is a clinically distinctive syndrome. Its pathogenesis is complex and only partially understood, but the essential features of its natural history are not disputed. Its prevalence has been estimated at about 1 in 10,000 of the population per anmum. A genetic predisposition to it is probable, ${ }^{2}$ though the mode of inheritance is uncertain. The disease is known to be associated with vitiligo and with thyroid disease. The course of an attack is not influenced in any consistent or predictable fashion by puberty, pregnancy, or the menopause. Thus there appears to be no logical reason why oral contraceptives should induce attacks of alopecia areata, and no acceptable statistics have yet been published to show that the disease is more frequent in women taking contraceptives than in matched controls.

Diffuse alopecia presents a more difficult problem, since its clinical diagnostic criteria are usually poorly defined and it certainly comprises several syndromes of very different origin. More than ten years ago, and well before the era of oral contraceptives, dermatologists in Europe and the United States reported an increased incidence of diffuse alopecia in their clinics, but were unable to establish whether this reflected an increased prevalence or merely a rising level of awareness of symptoms previously accepted as the inevitable concomitants of ageing.

\footnotetext{
' Bakker, C B., and Dightman, C. R., Obstet. and Gynec., 1966, 28, 373.

- Bckert. J., Church, R. E., Ebling, F. J., and Munro, D. S., Brit. F. Derm., 1967, 79, 543.

- Cormia, F. E., f. Amer. med. Ass., 1967, $201,635$.

- Lynfield, Y. L., F. invest. Derm., 1960, 35, 323.
}

Three processes may give rise to more or less diffuse thinning of the hair. With age there is some reduction over the whole scalp in the number of hair follicles, but there is wide individual variation in its severity. Superimposed on that is the transformation of some of the normal terminal follicles at the temples and on the vertex into small inconspicuous vellus (or tine hair) follicles. This process, which causes the familiar patterned alopecia so common in men, certainly occurs in some women genetically predisposed to it, but how frequently is still uncertain. But there is no doubt that in genetically predisposed women androgen of any origin can induce the transformation or increase its severity. Finally, there are the many general disturbances which may lead to a reversible increase in the normal loss of hair. Fever, parturition, surgical shock, and severe emotional stress are common provocative factors. Iron deficiency, drugs, especially the anticoagulants, and endocrine disorders, notably hypothyroidism, can sometimes be reliably identified as causing alopecia. J. Eckert and her colleagues ${ }^{2}$ in Sheffield have recently published an excellent account of 150 cases of diffuse alopecia ; they found no associated factors in 68 of their patients.

F. E. Cormia ${ }^{3}$ has reported five cases of alopecia which he attributes to oral contraceptives. It is true that some progestogens may have a masculinizing effect on some women. It is possible that alopecia of a male pattern could be induced in genetically predisposed women. However, the oral contraceptives bring about a "pseudo-pregnancy." In pregnancy normal cyclical loss of hair is in fact temporarily retarded. ${ }^{4}$ No information is available on the effects on hair follicles of pseudo-pregnancy maintained indefinitely. Theoretically it is possible that oral contraceptives could induce alopecia of male pattern in predisposed women and perhaps they could disturb the delicate endocrine mechanisms regulating the hair cycles, but so far there seems to be no evidence that they do.

\section{A Virus in Glandular Fever?}

There has always been a suspicion that glandular fever might be due to a virus. But repeated efforts to isolate one have proved fruitless, ${ }^{1}$ and attempts to transmit the disease to volunteers have given equivocal results. ${ }^{2}$ Now there is news from the United States of promising if not conclusive evidence that a virus may have some part in this disease.

The virus concerned is the herpes-like virus found in several of the cultures of cells derived from Burkitt's lymphoma ${ }^{3-5}$ This highly malignant tumour of lymphoid tissue, common among African children and found also outside Africa, ${ }^{6-8}$ has also long been suspected of having an infective cause. The virus now found is similar in structure to the other human herpes viruses-namely, herpes simplex, varicella, and cytomegaloviruses ${ }^{9-11}$ but is serologically distinct from them. ${ }^{12}$ It cannot be freed from Burkitt lymphoma cells or subcultured in other cells by conventional techniques. ${ }^{4}$ The virus was first detected in Burkitt lymphoma cells by electronmicroscopy, which also showed that not every cell harboured virus. The proportion of cello containing virus varied from $0.5 \%$ to $10 \%$, the proportion depending on the particular line of cells used. ${ }^{9}$ Later it was 
found that sera from patients with Burkitt's lymphoma gave intense staining in tests for immunofluorescence with the cells in culture, ${ }^{12-14}$ and this technique has been developed as a means of detecting antibody to the virus. Though it is not easy to prove that antibody in the fluorescent test reacts with virus and not some cellular antigen, the evidence suggests that it does. Examination of individual fluorescent cells in the electronmicroscope showed that they contained numerous virus particles, whereas no particles were seen in nonfluorescent cells. ${ }^{15}$ It has also been shown that absorption of sera with Burkitt lymphoma cells which did not contain virus failed to remove the antibody and that antibody molecules were seen coating and in some instances agglutinating virus particles which had been extracted from cells and treated with serum. ${ }^{16}$

The discovery that the virus might be implicated in glandular fever arose when Gertrude and Werner Henle and V. Diehl ${ }^{17}$ observed that leucocytes from a technician in their laboratory developed immunofluorescence after an attack of glandular fever. This suggested that the leucocytes contained the virus present in Burkitt lymphoma cells. Examination of blood samples showed that antibody was present six days after the onset of illness but that there was no antibody in a specimen taken seven months previously. Further investigations showed that every one of 42 patients with glandular fever possessed antibody which reacted in tests of fluorescence with Burkitt lymphoma cells. Fortunately, the Henles were also able to examine sera collected by J. C. Niederman and R. W. McCollum in a prospective study of glandular fever in students at Yale University. ${ }^{18}$ Sera had been obtained from every student soon after arrival at the university, so that baseline sera taken before the onset of illness were available from 29 students who subsequently developed glandular fever. All 29 students were shown to have high titres of antibody in sera collected during the illness, but there was no antibody in any of the specimens taken at the start of their student career. In contrast, the incidence of antibody in a control group of 50 healthy students was only $24 \%$. The students with glandular fever also had high titres of heterophile antibody to sheep red cells in the PaulBunnell reaction, but tests showed that this antibody was different from the other. Many questions remain unanswered. Provided tests of immunofluorescence do in fact show up antibody to the herpes-like virus-and though this seems highly probable it is not yet proved beyond doubt-the role

' Evans, A. S., Amer. F. Hyg., 1960, 71, 342.

- Evans, A. S., F. clin. Invest., 1950, 29, 508.

- Epstein, M. A., Achong, B. G., and Barr, Y. M., Lancet, 1964, 1, 702.

- Stewart, S. E., Lovelace, E., Whang, J. J., and Ngu, V. A., f. nat. Cancer Inst., 1965, 34, 319.

- Epstein, M. A., Achong, B. G., and Pope, J. H., Brit. med. F., 1967, 2, 290.

- Brit. med. f., 1968, 1, 332.

- Burkitt, D., Nature (Lond.), 1962, 194, 232.

Burkitt, D., Brit. med. f., 1962, 2, 1019.

- Hummeler, K., Henle, G., and Henle, W., f. Bact., 1966, 91, 1366.

- Toplin, I., and Schidlovsky, G., Science, 1966, 152, 1084.

Yamaguchi, J., Hinuma, Y., and Grace, J. T., F. Virol., 1967, 1, 640.

Henle, G., and Henle, W., f. Bact., 1966, 91, 1248.

Levy, J. A., and Henle, G., f. Bact., 1966, 92, 275.

1 Hinuma, Y., Konn, M., Yamaguchi, J., Wudarski, D. J., Blakeslee, J. R., and Grace, J. T., f. Virol., 1967, 1, 1045.

is Zur Hausen, H., Henle, W., Hummeler, K., Diehl, V., and Henle, G. f. Virol., 1967, 1, 830

- Henle, W., Hummeler, K., and Henle, G., f. Bact., 1966, 92, 269.

"Henle, G., Henle, W., and Diehl, V., Proc. nat. Acad. Sci. (Wash.), $1968,59,94$.

1 Niederman, J. C., McCollum, R. W., Henle, G., and Henle, W., f. Amer. med. Ass., 1968, 203, 205. of the virus in human populations is obscure. Surveys have indicated that infection with the virus is widespread. For instance, antibody has been found in $35 \%$ of American children seen as paediatric patients and in $54 \%$ of healthy African children. ${ }^{13}$ The incidence in patients with Burkitt's lymphoma, like those with glandular fever, is $100 \%$, but the relationship of the virus to Burkitt's lymphoma remains unknown. Perhaps the virus causes frequent though usually symptomless infection in man but can on occasion give rise to the symptoms of glandular fever. It is also possible that it is merely a passenger virus which becomes activated by the onset of some unrelated disease such as glandular fever.

\section{Cyclamates}

Additives to food arouse considerable passion not only in those who see a world short of food but also in those who firmly believe that food should remain pure and entirely unadulterated. This emotion is rarely justified, since most additives are permitted in only minute amounts in food and then after considerable scrutiny of any toxicological hazard In the case of the Minister's regulation permitting the use of cyclamates generally as a substitute for sugar, however, public anxiety is natural and politicians and the press, usually sensitive to public feeling, have commented extensively. Much of this comment has been very selective in its content and has been based on information frequently taken out of context. Scrutiny of the Government White Paper ${ }^{1}$ shows that few food additives have been studied as extensively as cyclamates. The references in the paper range over the period 1950-65 and include toxicity studies on isolated tissues, as well as on mice, rats, cats, rabbits, dogs, and monkeys, and five separate studies of the effects of cyclamates on children and adults. The report points out that in only one respect are the data short of that considered ideal ${ }^{2}$ for food additives-long-term feeding studies have been carried out on only one species. It recommends that a second species should be exposed to longterm feeding. Only one side-effect of cyclamates is knownin large doses they cause softness of the stools and, in larger doses, diarrhoea. This may or may not be a purely osmotic effect. The Pharmacology Subcommittee of the Ministry of Health clearly believed that the other effects noted in studies on animals were secondary to long-standing diarrhoea produced in the test animals. Changes in the texture of the stools can be expected to occur at doses of more than 100$150 \mathrm{mg} . / \mathrm{kg}$./day. A few cases of skin. sensitivity in man have been reported (see p. 630). The Pharmacology Subcommittee recommended in their report that the daily intake should not exceed $50 \mathrm{mg}$. $/ \mathrm{kg}$.- -about $3.5 \mathrm{~g}$. daily in an adult

For technical reasons it is impossible to replace atl the sugar in the diet by cyclamates, since most articles and foods containing sugar depend for their texture, traditional appearance, and the way they are made on qualities which only sugar has. Experience in the U.S.A., where cyclamates have been freely permitted in slimming food and drinks for ten years, suggests that up to $3 \frac{1}{2} \%$ of the sugar intake may in fact be replaced by saccharin or cyclamates or both. If this

\footnotetext{
' Report on Cyclamates, 1966, 24-9999. H.M.S.O.

- Memorandum on Procedure for Submissions on Food Additives and on Methods of Toxicity Testing, 1965, 24-9999. H.M.S.O.

second Report on Cyclamates, 1967, 24-9999. H.M.S.O.
} 